University of Nebraska - Lincoln

DigitalCommons@University of Nebraska - Lincoln

Faculty Publications: Department of

Entomology

Entomology, Department of

2019

Composition and Host-Use Patterns of a Scarab Beetle

(Coleoptera: Scarabaeidae) Community Inhabiting the Canopy of

a Lowland Tropical Rainforest in Southern Venezuela

Susan Kirmse

Zum Pichoblick 6, susankirmse@gmx.net

Brett C. Ratcliffe

University of Nebraska-Lincoln, bratcliffe1@unl.edu

Follow this and additional works at: https://digitalcommons.unl.edu/entomologyfacpub

Part of the Entomology Commons

Kirmse, Susan and Ratcliffe, Brett C., "Composition and Host-Use Patterns of a Scarab Beetle (Coleoptera: Scarabaeidae) Community Inhabiting the Canopy of a Lowland Tropical Rainforest in Southern Venezuela" (2019). Faculty Publications: Department of Entomology. 799.

https://digitalcommons.unl.edu/entomologyfacpub/799

This Article is brought to you for free and open access by the Entomology, Department of at DigitalCommons@University of Nebraska - Lincoln. It has been accepted for inclusion in Faculty Publications: Department of Entomology by an authorized administrator of DigitalCommons@University of Nebraska - Lincoln. 


\title{
Composition and Host-Use Patterns of a Scarab Beetle (Coleoptera: Scarabaeidae) Community Inhabiting the Canopy of a Lowland Tropical Rainforest in Southern Venezuela
}

\author{
SusAn KIRMSE \\ Zum Pichoblick 6 \\ 02633 Gaussig, GERMANY \\ susankirmse@gmx.net \\ AND \\ BRett C. Ratcliffe \\ Systematics Research Collections, W436 Nebraska Hall \\ University of Nebraska \\ Lincoln, NE 68588-0514, USA \\ bratcliffe1@unl.edu
}

\begin{abstract}
The adult scarab beetle fauna of the canopy in a lowland tropical rainforest in southern Venezuela was observed and collected by means of a 42-m-tall tower crane for a complete year. This first census of an entire Amazonian canopy scarab community was embedded within the interdisciplinary research project "Towards an understanding of the structure and function of a Neotropical rainforest ecosystem with special reference to its canopy" organized by the Austrian Academy of Science. The Scarabaeidae represented one of the most species-rich beetle families in the canopy of the crane plot and were therefore selected for a detailed analysis of host-use patterns. Thirty-three species of Scarabaeidae with 399 individuals were recorded, including two species represented by singletons. Subfamilies abundant in the canopy were the Rutelinae, Dynastinae, and Melolonthinae. Species were diurnal or nocturnal flower visitors restricted in their occurrence to their host trees during the flowering season. The scarab beetles remained commonly on one host tree species throughout the entire flowering period and switched to another host tree species only after depletion of food resources. Some species fed on extrafloral nectar but feeding on fruits and leaves was uncommon in the observed species. Most species showed a broad host range, often with abundant species recorded on several host trees. Seven species were found exclusively on one tree species. The co-occurrence of up to five congeneric species sharing the same host trees and diet was conspicuous. With this study, it could be shown how species of Scarabaeidae track available food resources within the canopy of a tropical rainforest.
\end{abstract}

Key Words: Neotropics, diversity, diel activity, behavior, host specificity, diet

DOI.org/10.1649/0010-065X-73.1.149

... and from the canopy high above came a constant rain of fruit, twigs, and pirouetting blossoms thrown down by the great army of creatures mammals, birds, reptiles, and insects that inhabit this high, sunlit, flower-scented realm. - Gerald Durrell, May 1986

Scarab beetles comprise a speciose family, and they are a conspicuous component of the beetle fauna in the New World. The group includes over 27,800 species worldwide. Scarab beetles in the New World comprise approximately 600 genera (Ratcliffe and Jameson 2005). Life histories of scarab beetles are incredibly diverse and include adults that feed on dung, carrion, fungi, leaves, pollen, fruits, compost, and roots, and some are also attracted to sap flows. Adults of some scarab beetles are diurnal and can be observed on flowers or vegetation, while many other species are nocturnal and may be attracted to lights at night. Adults of most species in the subfamilies Melolonthinae, Dynastinae, Rutelinae, and Cetoniinae feed on plants. Eggs are deposited by the adult female in suitable soil, dung, compost, or other organic material. After hatching, the C-shaped grubs feed and grow, molting three times. Larvae of many dynastines and rutelines feed on rotting wood, and the larvae of many melolonthines, rutelines, and dynastines (e.g., Cyclocephala Dejean) feed on grass roots. Emergence of the adult from the pupa often occurs in response to environmental cues such as rainfall or temperature. After emergence, adults mate and begin the cycle anew. The biology and behavior of many species of scarabs are not known, and much remains to be studied (Ritcher 1958; Ratcliffe 1991; Scholtz and Chown 1995). 
There are numerous records of host plants as well as studies dealing with the life history of scarab beetles, but little has been known about beetles inhabiting the canopy of tropical rainforests (Erwin 1994), including species of Scarabaeidae. Tropical rainforests contain a tremendously rich beetle fauna, and hundreds of beetle species are associated with tree canopies (Erwin 1982; Stork 1991; Basset and Arthington 1992; Allison et al. 1993). The canopy biome is extremely complex in terms of trophic levels, architecture, and seasonality. The ecological connections between and among the plants and animals are poorly known as well as the composition of the still incompletely known fauna (Arndt et al. 2001). The major hypotheses concerning the enormous diversity either invoke the complex interactions of the insect herbivores and plants (due to host specificity and niche partitioning associated with plant defense systems) or the correlation with host plant phylogenetic diversity, which is highest in tropical regions (Coley and Barone 1996; Novotny et al. 2006).

Another aspect of canopy beetle communities is their high faunal turnover. See, for example, the refogging experiments indicating that recruitment of beetle assemblages is often stochastic (Erwin 1990; Adis et al. 1998; Floren and Linsenmair 1998). In scarab beetle assemblages in the premontane rainforest in Costa Rica, the species richness, as well as the species composition, showed significant variation across the same ecosystem at both spatial and temporal scales, suggesting a high species turnover (García-López et al. 2010). The interaction between resource and host specificity defines the broad limits of insect diet and distribution within canopy environments (Schoonhoven et al. 2005). Resource availability is the most important factor driving spatial and temporal distribution patterns among arboreal insect assemblages (Wardhaugh 2014).

However, the survey of rainforest insect communities adequately requires long-term sampling at multiple sites using multiple sampling methods (Adis et al. 1984; Kitching et al. 2001; Stork and Grimbacher 2006; Basset et al. 2012). Only then is it possible to confidently quantify the forces and mechanisms influencing the distribution and structure of rainforest insect communities, enabling accurate predictions of spatial and temporal distribution patterns (Wardhaugh 2014).

Our study was designed to discover the underlying mechanisms of the coexistence of a diversity of scarab beetle species and the causes for stochastic patterns in species composition and distribution among the trees. The focus was to find out where scarab beetles occur, upon what do they feed, and how they behave. The requirements for surveying rainforest insect communities were met with the study design used to investigate the canopy beetle community in the northern part of the Amazon Basin with the only crane constructed in this complex biome. Non-invasive trapping complemented with hand-collection and regular observations were combined and carried out during the day as well as the night. The study is the first that provides observations on an entire scarab community collected during a complete year. It includes data of occurrence, diet, and utilized hosts of adult Scarabaeidae inhabiting the canopy of a tropical lowland rainforest in southern Venezuela. Furthermore, it gives insight into adult scarab species composition within the canopy and the behavior of abundant species. Until now, there were no published detailed studies on canopy scarab communities in tropical rainforests. In general, canopy studies at fine taxonomic resolution are scarce, probably due to difficulties in maintaining longterm sampling programs, identifying species, and sorting large numbers of insects in the tropics (Grimbacher and Stork 2009).

\section{Material ANd Methods}

Study Site. The study site was located in the upper Orinoco region of Venezuela in the state of Amazonas, close to the Surumoni black water river $\left(3^{\circ} 10^{\prime} \mathrm{N}, 65^{\circ} 40^{\prime} \mathrm{W} ; 105 \mathrm{~m}\right.$ elevation). Anhuf et al. (1999) described the weather pattern as heavy annual rainfall of about 3,100 $\mathrm{mm}$ (with year to year fluctuations of about $500 \mathrm{~mm}$ ) with a strong peak from May to July, then a smaller peak in September and October. The average annual temperature in the study area was $c a .26^{\circ} \mathrm{C}$, usually with slight variations between the coolest month $\left(25^{\circ} \mathrm{C}\right)$ and the warmest month $\left(26.5^{\circ} \mathrm{C}\right)$, whereas a daily range of $5-10^{\circ} \mathrm{C}$ frequently occurs.

The Surumoni area belongs to the Japura/Negro moist forests ecoregion that extends from Brazil to southern Venezuela, Colombia, and Peru (Dinerstein et al. 1995). The vegetation is moist lowland tropical rainforest classified as terra firme (Prance 1979). The upper canopy is $25-27 \mathrm{~m}$ in height. Only a few emergent trees rise to a height of $35 \mathrm{~m}$. The forest is frequently interrupted by light gaps, thus, the canopy is not completely closed. The Surumoni canopy crane plot contains average tree species richness for the area. There were more than 800 trees $\geq 10 \mathrm{~cm} \mathrm{DBH}$ (diameter at breast height) belonging to 141 tree species within the study site. Frequent species in the tree fraction with a DBH of $\geq 10 \mathrm{~cm}$ were Goupia glabra Aubl. (Goupiaceae), Oenocarpus bacaba Mart. (Arecaceae), Dialium guianense (Aubl.) Sandwith (Fabaceae), Ocotea aff. amazonica (Meisn.) Mez (Lauraceae), and Ruizterania trichanthera (Spruce ex Warm.) Marc-Berti (Vochysiaceae) (Wesenberg 2004). Epiphytes and hemiepiphytes were rare compared 
to other moist forests and comprised 53 species, with Araceae reaching the highest abundance (Engwald et al. 2000).

Sampling and Observation. Sampling and observation of scarab beetles was conducted from 1997 to 1999 and covered a complete year. A 42-mhigh canopy crane system (Fig. 1) was installed at the study site, and its swing covered an area of about 1.4 ha. Using this large tower crane, the crowns of tree species (Fig. 2) in the upper and middle canopy were searched regularly for species of Scarabaeidae during the day as well as during the night. Observations and collection of beetles were carried out during the following periods: September to November 1997; May to August and December 1998; January to April and November 1999.

Beetles were captured by net, hand-collected, or through branch and foliage beating. Beating was used to capture hidden or tightly clinging species and netting to get flying beetles. Both methods were predominately used to capture distant beetles. There was no quantitative sampling carried out with these methods. Additionally, aerial window traps were used to collect flying beetles (Basset et al. 1997). These window traps consisted of two panels of plexiglass fixed in a cross pattern with each panel $30-\mathrm{cm}$-long and $25-\mathrm{cm}$-high. Beneath the plexiglass panels was a plastic tube ending in a container for collecting the insects (Fig. 3). These traps provided semi-quantitative sampling results. A spotlight that attracted nocturnal scarabs was used to enable observations at night. Some of these attracted individuals were collected as well to gain data on seasonality. Furthermore, this indicates that such species can occur even when host trees were not found.

The collected beetles were kept in $70 \%$ ethanol. The beetles were assigned to morphospecies, with some of them identified by us. The family group names follow Bouchard et al. (2011). Voucher specimens of collected species are deposited in the Museo del Instituto de Zoología Agrícola "Francisco Fernández Yépez", Maracay, Venezuela, and the Botanisches Institut, Universität Leipzig, Germany.

In addition to the live observations, feeding trials were carried out with 22 species. Beetles were kept alone or in small groups of up to five individuals of a morphospecies in plastic tubes. The tubes (about $12 \mathrm{~cm}$ high and with a diameter of about $15 \mathrm{~cm}$ ) were filled with loam to a height of nearly $3 \mathrm{~cm}$. They were then alternately provided with mature and young leaves of the host tree and related tree species. Herbivory was checked every second day and scored visually either as non-feeding, attempting to feed, or frequently feeding. Species that fed regularly on parts of the leaf blade were considered as leaf feeders. Attempting to feed included all damage to the plant items without visible loss of substance. In addition, fruits and flowers were offered. Adult scarabs were kept under the natural temperature and humidity regime as well as natural photoperiod for the area for several weeks or until they died, respectively. The feeding trials were used to verify observations in the canopy.

Ecological Characteristics. Many scarabs fed on young foliage or fruits in the feeding trials. However, this usually could not be confirmed through observations in the canopy. Due to this discrepancy, only data and observations gained in the canopy were considered to characterize the species ecologically. The ability to locate and identify a preferred host may have little in common with the ability to consume a distinct host (Singer 2008). Furthermore, limiting factors such as predators (Dyer 1995) or host-plant abundance and resource availability (Futuyma and Wasserman 1980) might have significant impacts on host-species and diet choice.

Species were assigned according to their diel activity either as nocturnal or diurnal species. The diet (plant tissue/parts) consumed were categorized as leaves, extrafloral nectaries, fruits, and flowers. Certain beetles visit only small white generalist flowers and other beetles visit many kinds of flowers, so consumed flowers were categorized either as small white generalist or diverse flowers comprising all other floral syndromes. Host associations were first scaled according to the number of individuals sampled on a certain tree species and second according to feeding observations. Due to data not equally quantified, host specificity indices were not calculated. Thus, the main hosts harbored the most individuals and include most feeding observations. Species with only one host record might also comprise individuals attracted to lights. In contrast, species collected with all individuals on only one canopy host plant are indicated as exclusive species. The main diet includes food items that were regularly consumed in the canopy. Abundant species were determined by their proportion of all scarabs sampled on one distinct canopy host during a given phenological season.

Data Presentation. The members of the scarab community reported here include only species with recorded host associations sampled in the canopy of the crane plot. To exclude random findings, only species that were relatively abundant on the sampled trees or displayed substantial or distinct feeding observations, respectively, are described in the results section. The same principle applies to the choice of host trees named and described, respectively. In general, only host trees with the most sampled individuals were considered as host trees and named, although feeding observations on single specimens might indeed indicate true host 

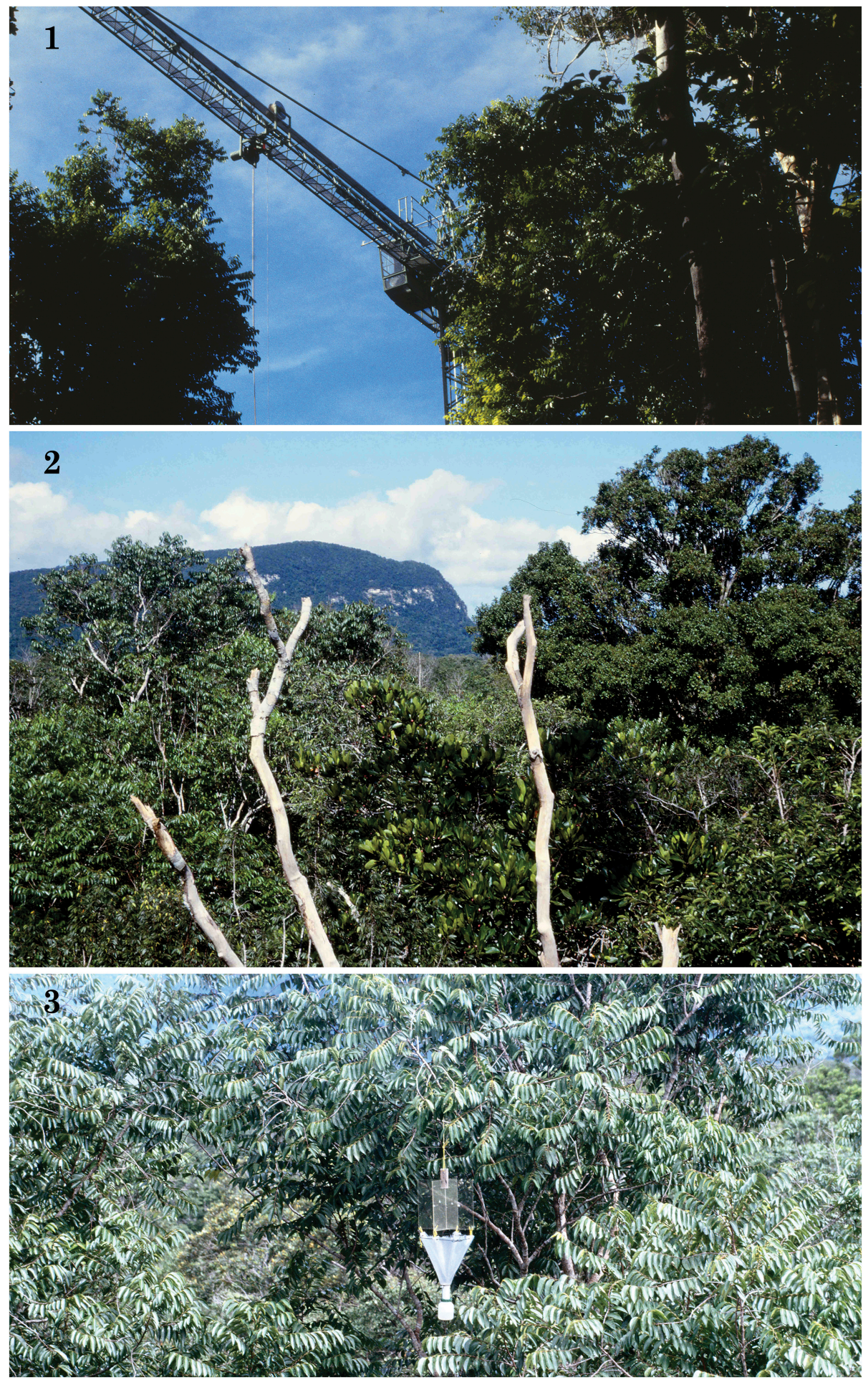

Figs. 1-3. Study site in Venezuela. 1) Crane used for access to the canopy of the lowland rainforest; 2) Canopy of the lowland rainforest; 3) Window trap in the canopy of the crane plot. 
associations. Host trees that revealed the most species of scarabs are described in detail.

\section{Results}

Overview. Thirty-three species of Scarabaeidae with 399 individuals were collected in the canopy of the study plot (Table 1$)$. Twenty species $(60.6 \%)$ were collected with less than 10 individuals per species, including two species represented by singletons and five species by doubletons. Thirteen species $(39.4 \%)$ were collected with at least 10 individuals per species. Most species sampled belong to the subfamily Melolonthinae (14 species) followed by Dynastinae (nine species) and Rutelinae (eight species). Aphodiinae and Cetoniinae were each represented by only a single species. The most species-rich genera associated with the canopy were Macraspis MacLeay (seven species), Cyclocephala (five species), and Pelidnota MacLeay (four species).

Beetle species were collected in different proportions using the sampling methods. The window traps captured 16 scarab species with 76 individuals, but only three species were trapped with at least 10 individuals: Isonychus Mannerheim sp. $2(n=22)$; Cyclocephala ovulum Bates $(n=22)$; and Macraspis

Table 1. Overview of 33 scarab beetle species recorded in the canopy of a lowland tropical rainforest in Venezuela, 1997-1999. Exclusive = all sampled individuals were on only one host tree; 1 host species = only one host tree species, but more individuals were collected at lights; EFN = extrafloral nectar.

\begin{tabular}{|c|c|c|}
\hline Species & \# individuals / \# host species & Diet \\
\hline $\begin{array}{l}\text { DYNASTINAE } \\
\text { Cyclocephala bicolor Castelnau, } 1840 \\
\text { Cyclocephala colasi Endrödi, } 1964 \\
\text { Cyclocephala minuta Burmeister, } 1847 \\
\text { Cyclocephala ovulum Bates, 1888 } \\
\text { Cyclocephala picipes (Olivier, 1789) } \\
\text { Stenocrates rufipennis (Fabricius, 1801) } \\
\text { Stenocrates cf. carbo Prell, 1938 } \\
\text { Phileurus valgus (Linnaeus, 1758) } \\
\text { Tomarus ebenus (De Geer, 1774) }\end{array}$ & $\begin{array}{l}2 / \text { exclusive } \\
24 / 2 \\
32 / 1 \\
68 / 4 \\
3 / 1 \\
3 / 1 \\
21 / 4 \\
1 / \text { exclusive } \\
17 / 3\end{array}$ & $\begin{array}{l}\text { EFN } \\
\text { flowers } \\
\text { flowers } \\
\text { EFN, flowers } \\
\text { small white flowers } \\
? \\
\text { EFN, fruit } \\
\text { EFN } \\
\text { flowers }\end{array}$ \\
\hline $\begin{array}{l}\text { MELOLONTHINAE } \\
\text { Melolonthinae sp. } \\
\text { Barybas sp. } 1 \\
\text { Barybas } \text { sp. } 2 \\
\text { Barybas } \text { sp. } 3 \\
\text { Dicrania } \text { sp. } \\
\text { Isonychus } \text { sp. } 1 \\
\text { Isonychus } \text { sp. } 2 \\
\text { Plectris } \text { sp. }\end{array}$ & $\begin{array}{l}5 / 3 \\
2 / 2 \\
3 / 2 \\
13 / 7 \\
3 / \text { exclusive } \\
3 / 2 \\
25 / 3 \\
6 / \text { exclusive }\end{array}$ & $\begin{array}{l}\text { flowers } \\
\text { small white flowers } \\
? \\
\text { EFN, flowers } \\
\text { flowers } \\
\text { flowers } \\
\text { flowers } \\
\text { EFN }\end{array}$ \\
\hline $\begin{array}{l}\text { RUTELINAE } \\
\text { Leucothyreus } \text { sp. } \\
\text { Cnemida leprieuri Arrow, 1899 } \\
\text { Cnemida retusa (Fabricius, 1801) } \\
\text { Macraspis festiva Burmeister, 1844 } \\
\text { Macraspis nr. maculata Burmeister, } 1844 \\
\text { Macraspis pseudochrysis Landin, } 1956 \\
\text { Macraspis sp. } 1 \\
\text { Macraspis sp. } 2 \\
\text { Macraspis } \text { sp. } 3 \\
\text { Macraspis } \mathrm{sp} .4 \\
\text { Pelidnota aciculata (F. Bates, 1904) } \\
\text { Pelidnota } \text { osculatii Guérin-Méneville, } 1855 \\
\text { Pelidnota polita complex } \\
\text { Pelidnota } \text { sp. } 1\end{array}$ & $\begin{array}{l}5 / 1 \\
12 / 2 \\
46 / 3 \\
32 / 4 \\
11 / 3 \\
3 / \text { exclusive } \\
2 / \text { exclusive } \\
2 / 2 \\
3 / 2 \\
1 / \text { exclusive } \\
5 / 1 \\
22 / 7 \\
3 / \text { exclusive } \\
2 / \text { exclusive }\end{array}$ & $\begin{array}{l}\text { leaves } \\
\text { fowers, fruit } \\
\text { flowers } \\
\text { flowers } \\
\text { flowers } \\
\text { small white flowers } \\
\text { small white flowers } \\
\text { small white flowers } \\
\text { small white flowers } \\
\text { small white flowers } \\
\text { flowers } \\
\text { EFN, flowers } \\
\text { EFN } \\
\text { small white flowers }\end{array}$ \\
\hline $\begin{array}{l}\text { APHODIINAE } \\
\text { Auperia } \text { sp. }\end{array}$ & $12 / 1$ & flowers \\
\hline $\begin{array}{l}\text { CETONIINAE } \\
\text { Hoplopyga liturata (Olivier, 1789) }\end{array}$ & $7 / 1$ & flowers \\
\hline Total & & $399 / 71$ \\
\hline
\end{tabular}


festiva Burmeister ( $n=10$ ) (Fig. 4). Three scarab species (Phileurus valgus (Linnaeus), Dicrania Le Peletier and Audinet-Serville sp., and Isonychus sp. 1) were taken only in the traps. The majority of species $(n=29)$ were sampled by hand, with nine species recorded only by hand-collecting methods. Abundant species collected mainly or exclusively by hand comprised the rutelines M. festiva $(n=20)$, Macraspis nr. maculata Burmeister $(n=11)$, Pelidnota osculatii Guérin-Méneville $(n=18)$, Cnemida leprieuri Arrow $(n=11)$, and Cnemida retusa (Fabricius) $(n=42)$.

Most scarab species $(n=25 ; 75.8 \%)$ were recorded on flowers (Table 1). Twenty-one of these 25 species were found exclusively on flowers. Eight of the 21 exclusive flower visitors were found only on small white flowers of the generalist syndrome. Eight scarab species $(24.2 \%)$ were observed feeding on extrafloral nectaries, four of which were found exclusively consuming this diet (Table 1). Feeding on fruits seems to be uncommon for canopy scarabs (two species); Stenocrates cf. carbo Prell was seen feeding on unripe fruits of $O$. aff. amazonica. Only one species, Leucothyreus MacLeay sp., was assigned as leaf-feeding.

Seven scarab species ( $21.2 \%$ of total) with at least two collected individuals were found exclusively on one tree species. Conversely, 10 species (30.3\%) were found on at least three different host tree species. Most species sampled with at least 10 individuals were recorded on several host-tree species. A regression line between the number of scarab specimens per

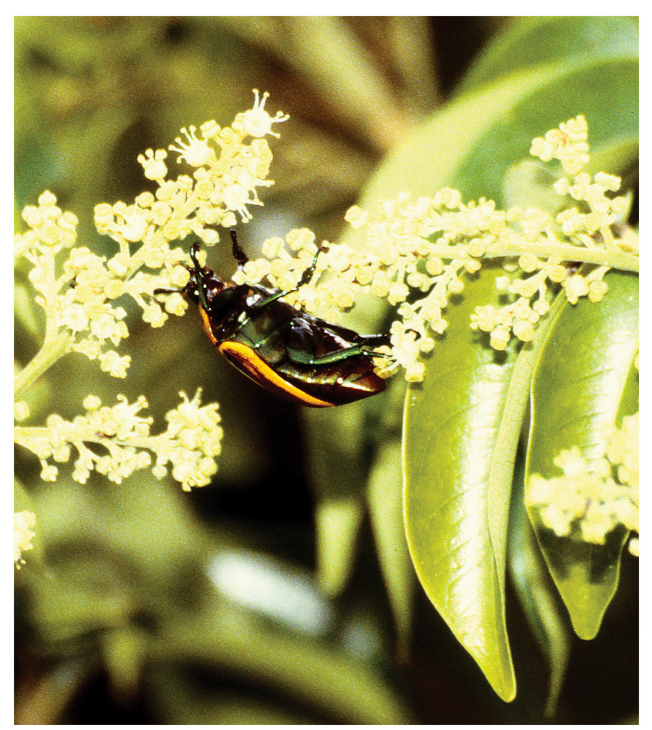

Fig. 4. Macraspis festiva feeding on flowers of Matayba guianensis in the canopy of the crane plot, Venezuela, 1997. species sampled on the canopy trees and the number of host trees confirms this tendency (Fig. 5).

Scarabaeidae were recorded primarily from the following 13 tree species and two other canopy plants (Table 2): Albizia pedicellaris Barneby and Grimes, Senna cf. silvestris (Vell.) H. S. Irwin and Barneby, and Tachigali guianensis (Benth.) Zarucchi and Herend (all Fabaceae); G. glabra; Licania hebantha Mart. ex Hook. f., Hymenopus heteromorphus (Benth.) Sothers \& Prance, and Moquilea subarachnophylla (Cuatrec.) Sothers \& Prance (all Chrysobalanaceae); Matayba guianensis Aubl. (Sapindaceae); O. aff. amazonica; Qualea paraensis Ducke and $R$. trichanthera (both Vochysiaceae); Emmotum acuminatum (Benth.) Miers (Metteniusaceae); Guatteria schomburgkiana Mart. (Annonaceae); the mistletoe Phthirusa stelis (L.) Kuijt (Loranthaceae); and the liana Dioclea scabra (Rich.) R. H. Maxwell (Fabaceae).

Species Characteristics. Dynastinae observed in our study were nocturnal and mostly attracted to lights. Four dynastine species comprising three species of Cyclocephala and Tomarus ebenus (De Geer) fed only on flowers (Table 1). Two species, Cyclocephala bicolor Castelnau and $P$. valgus, were associated with extrafloral nectaries. One species, $S$. cf. carbo, fed on fruit and extrafloral nectar. Cyclocephala ovulum was observed utilizing flowers of $A$. pedicellaris, $M$. guianensis, and $Q$. paraensis and extrafloral nectaries of $M$. subarachnophylla. This beetle species demonstrated temporally restricted flower constancy during the flowering season of $A$. pedicellaris when 20 individuals were collected only from flowers of this tree during 11-19 October 1997.

Eight species of Melolonthinae were collected, including seven demonstrating nocturnal activity (Table 1). Five melolonthine species in the genera

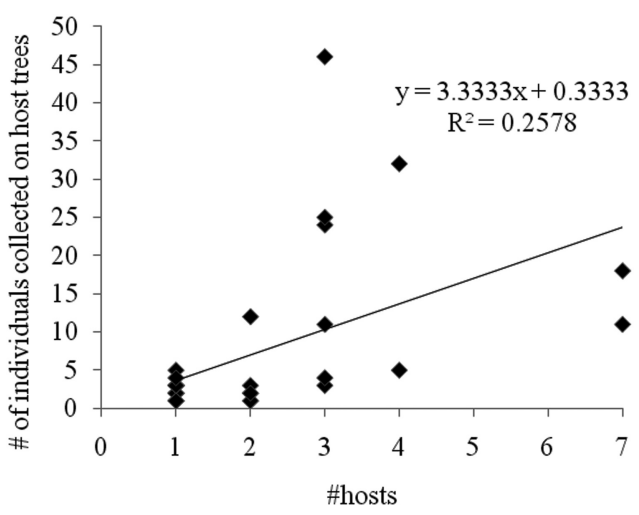

Fig. 5. Number of individuals sampled per scarab beetle species on host trees regressed on the number of utilized host trees, Venezuela, 1997-1999. 
Table 2. Monitored tree species, total number of scarab species associated with each tree species, number of scarab species found exclusively on the tree species, number of scarab species feeding on flowers, extrafloral nectaries (EFN), and/ or fruits of the tree species, and scarab species represented by three or more individuals and their diet on each tree species in a lowland tropical rainforest canopy in Venezuela, 1997-1999.

\begin{tabular}{|c|c|c|c|c|c|c|c|c|}
\hline Host tree species & Total & $\begin{array}{c}\# \text { species with } \\
n \geq 2\end{array}$ & $\begin{array}{c}\text { Species with } \\
\quad n \geq \mathbf{3}\end{array}$ & $n$ & Exclusive & Flowers & EFN & Fruits \\
\hline \multirow{2}{*}{$\begin{array}{l}\text { Hymenopus } \\
\text { heteromorphus }\end{array}$} & 12 & 6 & & & 2 & 12 & & \\
\hline & & & $\begin{array}{l}\text { Pelidnota osculatii } \\
\text { Isonychus } \text { sp. } 2 \\
\text { Macraspis festiva }\end{array}$ & $\begin{array}{l}7 \\
5 \\
4\end{array}$ & & $\begin{array}{l}\text { yes } \\
\text { yes } \\
\text { yes }\end{array}$ & & \\
\hline Matayba guianensis & 7 & 3 & $\begin{array}{l}\text { Isonychus sp. } 2 \\
\text { Macraspis festiva }\end{array}$ & $\begin{array}{l}19 \\
15\end{array}$ & 1 & $\begin{array}{c}7 \\
\text { yes } \\
\text { yes }\end{array}$ & & \\
\hline Goupia glabra & 6 & 5 & & & & 4 & & 1 \\
\hline Dioclea scabra & 5 & 3 & $\begin{array}{l}\text { Cnemida retusa } \\
\text { Cnemida leprieuri } \\
\text { Macraspis maculata }\end{array}$ & $\begin{array}{r}42 \\
11 \\
8\end{array}$ & & $\begin{array}{r}5 \\
\text { yes } \\
\text { yes } \\
\text { yes }\end{array}$ & & \\
\hline Ocotea aff. amazonica & 5 & 1 & & & & 5 & & 1 \\
\hline Albizia pedicellaris & 4 & 2 & Cyclocephala ovulum & 20 & & $\begin{array}{c}4 \\
\text { yes }\end{array}$ & & \\
\hline Tachigali guianensis & 4 & 2 & $\begin{array}{l}\text { Macraspis festiva } \\
\text { Macraspis pseudochrysis }\end{array}$ & $\begin{array}{l}7 \\
3\end{array}$ & $\begin{array}{c}1 \\
\text { yes }\end{array}$ & $\begin{array}{c}2 \\
\text { yes } \\
\text { yes }\end{array}$ & & \\
\hline $\begin{array}{l}\text { Moquilea } \\
\quad \text { subarachnophylla }\end{array}$ & 4 & 2 & Pelidnota osculatii & 3 & 1 & & $\begin{array}{c}4 \\
\text { yes }\end{array}$ & \\
\hline Qualea paraensis & 4 & 2 & & & & 4 & & \\
\hline Senna cf. silvestris & 4 & 1 & & & 1 & 1 & 1 & \\
\hline \multirow[t]{2}{*}{$\begin{array}{l}\text { Ruizterania } \\
\quad \text { trichanthera }\end{array}$} & 3 & 3 & & & 2 & 1 & 2 & \\
\hline & & & Plectris sp. & 5 & yes & & yes & \\
\hline Licania hebantha & 3 & 2 & $\begin{array}{l}\text { Pelidnota osculatii } \\
\text { Pelidnota polita } \\
\quad \text { complex }\end{array}$ & $\begin{array}{l}3 \\
3\end{array}$ & $\begin{array}{c}1 \\
\text { yes }\end{array}$ & & $\begin{array}{c}3 \\
\text { yes } \\
\text { yes }\end{array}$ & \\
\hline Phthirusa stelis & 2 & 1 & Barybas sp. 3 & 3 & & $\begin{array}{c}2 \\
\text { yes }\end{array}$ & & \\
\hline
\end{tabular}

Barybas Blanchard, Dicrania, and Isonychus were recorded only on flowers. Two species of Isonychus were found on flowers of $A$. pedicellaris and $H$. heteromorphus. Isonychus sp. 2 was found regularly during all flowering seasons of M. guianensis (Table 5) but was not observed feeding on the flowers. Two species of Barybas fed on flowers of P. stelis and $H$. heteromorphus, with Barybas sp. 3 found on five additional host tree species (Table 4). An undetermined species of Plectris Le Peletier and Audinet-Serville utilized exclusively extrafloral nectar.

In our study, 14 ruteline species were observed (Table 1). Nine species of Macraspis and Cnemida Kirby visited flowers in the daytime. Cnemida leprieuri and C. retusa fed regularly on flowers of the liana D. scabra and sometimes on flowers of other trees (Table 2). Cnemida retusa was found quiescent on the forest floor at night. The seven species of Macraspis recorded in the study plot (Table 1) visited a variety of flowers. Macraspis nr. maculata fed predominately on D. scabra. Five species occurred on flowers of M. guianensis and $H$. heteromorphus. Of these, four species were observed together on both tree species. Two Macraspis species were also found together on flowers of $T$. guianensis. The most abundant (with up to 25 specimens on one canopy tree) of the Macraspis species was M. festiva (Fig. 4), which fed on flowers of four tree species (Table 6). After the end of the flowering season of $M$. guianensis, $M$. festiva moved to a flowering $Q$. paraensis, and then to a flowering $T$. guianensis. This species was frequently 
Table 3. Host trees, diet, activity, and months of occurrence of 15 scarab beetle species in the canopy of a lowland tropical rainforest in Venezuela, 1997-1999. EFN = extrafloral nectaries. $(\# / \#)=$ first digit indicates number of monitored plant specimens, second digit indicates number of sampling points.

\begin{tabular}{|c|c|c|c|}
\hline & $\begin{array}{l}\text { \# host tree } \\
\text { species }\end{array}$ & Main diet & Main host trees \\
\hline Species & Activity & Months of occurrence & Remarks \\
\hline \multirow{2}{*}{$\begin{array}{l}\text { Cyclocephala } \\
\text { ovulum }\end{array}$} & 4 host species & diverse flowers & Albizia pedicellaris $(1 / 1)$ \\
\hline & nocturnal & $\begin{array}{l}\text { Jan, Feb 1999; Aug, } \\
\text { Dec 1998; Sep-Nov } 1997\end{array}$ & $\begin{array}{l}\text { copulation in Dec, oviposition in } \\
\text { Sep, Dec }\end{array}$ \\
\hline \multirow[t]{2}{*}{ Barybas sp. 1} & 2 host species & small white flowers & $\begin{array}{l}\text { Phthirusa stelis }(1 / 1) \text { Hymenopus } \\
\text { heteromorphus }(1 / 1)\end{array}$ \\
\hline & nocturnal & Mar 1999; Jul 1998 & \\
\hline \multirow[t]{2}{*}{ Barybas sp. 3} & 7 host species & diverse flowers $(+\mathrm{EFN})$ & $\begin{array}{l}\text { Phthirusa stelis }(1 / 1) \text { Hymenopus } \\
\text { heteromorphus }(1 / 1)\end{array}$ \\
\hline & nocturnal & $\begin{array}{l}\text { Mar 1999; Jun-Aug 1998; } \\
\text { Sep, Oct } 1997\end{array}$ & \\
\hline \multirow[t]{2}{*}{ Isonychus sp. 1} & 2 host species & diverse flowers & $\begin{array}{l}\text { Albizia pedicellaris }(1 / 1) \text { Hymenopus } \\
\text { heteromorphus }(1 / 1)\end{array}$ \\
\hline & nocturnal & Mar, Apr 1999 & \\
\hline \multirow[t]{2}{*}{ Isonychus sp. 2} & 3 host species & diverse flowers & $\begin{array}{l}\text { Matayba guianensis }(2 / 2) \\
\quad \text { Hymenopus heteromorphus }(1 / 1)\end{array}$ \\
\hline & nocturnal & $\begin{array}{l}\text { Sep, Oct 1997; Mar, May, } \\
\text { Oct, Nov } 1999\end{array}$ & \\
\hline \multirow[t]{2}{*}{ Plectris sp. } & 1 host species & EFN & Ruizterania trichanthera (4/1) \\
\hline & nocturnal & Jan-Mar 1999 & \\
\hline \multirow[t]{2}{*}{ Leucothyreus sp. } & 1 host species & leaves & Guatteria schomburgkiana (1/1) \\
\hline & nocturnal & Jun 1998; Aug 1997 & \\
\hline \multirow[t]{2}{*}{ Cnemida leprieuri } & 2 host species & diverse flowers & Dioclea scabra $(1 / 1)$ \\
\hline & diurnal & $\begin{array}{l}\text { Jan, Feb 1999; Oct 1997; } \\
\text { Dec } 1998\end{array}$ & mating in Dec and Feb \\
\hline \multirow[t]{2}{*}{ Cnemida retusa } & 3 host trees & diverse flowers & Dioclea scabra $(1 / 2)$ \\
\hline & diurnal & $\begin{array}{c}\text { Jan-Mar 1999; Jun, Jul 1998; } \\
\text { Sep, Nov 1997; Dec } 1998\end{array}$ & quiescent on the forest floor at night \\
\hline \multirow[t]{2}{*}{ Macraspis festiva } & 4 host species & diverse flowers & $\begin{array}{l}\text { Matayba guianensis }(2 / 1) \text { Tachigali } \\
\text { guianensis }(1 / 1)\end{array}$ \\
\hline & diurnal & Mar 1999; Sep-Nov 1997 & $\begin{array}{l}\text { frequently mating on flowering } M \text {. } \\
\text { guianensis; quiescent on leaf surface } \\
\text { of neighboring trees at night }\end{array}$ \\
\hline \multirow[t]{2}{*}{ Macraspis nr. maculata } & 3 host species & diverse flowers & Dioclea scabra $(1 / 2)$ \\
\hline & diurnal & $\begin{array}{l}\text { Mar 1999; Jun, Jul 1998; } \\
\text { Sep 1997; Dec } 1998\end{array}$ & \\
\hline \multirow[t]{2}{*}{ Pelidnota sp. 1} & 1 host species & small white flowers & Hymenopus heteromorphus $(1 / 1)$ \\
\hline & nocturnal & Mar 1999 & \\
\hline
\end{tabular}


Table 3. Continued.

\begin{tabular}{|c|c|c|c|}
\hline & $\begin{array}{l}\text { \# host tree } \\
\text { species }\end{array}$ & Main diet & Main host trees \\
\hline Species & Activity & Months of occurrence & Remarks \\
\hline \multirow[t]{2}{*}{ Pelidnota aciculata } & 1 host species & diverse flowers & Ruizterania trichanthera $(1 / 1)$ \\
\hline & nocturnal & Aug-Nov 1997 & \\
\hline \multirow[t]{2}{*}{ Pelidnota osculatii } & 7 host species & diverse flowers $(+\mathrm{EFN})$ & $\begin{array}{l}\text { Hymenopus heteromorphus }(1 / 1) \\
\text { Licania hebantha }(1 / 1)\end{array}$ \\
\hline & nocturnal & $\begin{array}{c}\text { Jan-Mar 1999; May-Jul } \\
\text { 1998; Aug, Oct } 1997\end{array}$ & oviposition in Mar \\
\hline \multirow[t]{2}{*}{ Pelidnota polita complex } & 1 host species & EFN & Licania hebantha $(1 / 1)$ \\
\hline & nocturnal & Jan, Feb 1999 & \\
\hline
\end{tabular}

seen mating on flowering $M$. guianensis. Specimens were observed resting on the leaf surfaces of two neighboring tree species at night.

Nocturnal ruteline species belong to the genera Leucothyreus and Pelidnota (Table 3). The four species of Pelidnota fed on flowers and extrafloral nectaries. Pelidnota osculatii (Table 7) and Pelidnota sp. 1 occurred together on the flowers of $H$. heteromorphus, while $P$. osculatii and a species from the Pelidnota polita (Latreille) complex fed on the extrafloral nectar on leaves of $L$. hebantha and occasionally bit into young leaves. The single species of Leucothyreus consumed leaves of $G$. schomburgkiana.

Host Trees. Hymenopus heteromorphus is massflowering and bears small white flowers of the generalist syndrome. There were buds on $H$. heteromorphus at the end of February 1999. With the opening of the first buds from 3 March onwards, flower-visiting beetles were observed regularly. Scarabaeidae represented the family with the fourth greatest species richness $(n=12)$ on this tree (Table 2$)$ and were represented by 28 individuals, including six trapped specimens. Two scarab species, Pelidnota sp. 1 and Macraspis sp. 1, were recorded exclusively on $H$. heteromorphus. Other species recorded on H. heteromorphus were Barybas sp. 1 and sp. 3, Isonychus sp. 1 and sp. 2, M. festiva, M. nr. maculata, Macraspis sp. 2 and sp. 3, P. osculatii, and T. ebenus.

Two trees of $M$. guianensis with mass-flowering had small white flowers of the generalist syndrome and were sampled during three flowering seasons. Tree \#446 was monitored over a flowering season of 21 days from 18 September to 8 October 1997. Three scarab specimens, one each of C. ovulum, Isonychus sp. 2, and M. festiva, were collected in the traps. Many $M$. festiva were observed mating on the tree but not usually captured in the traps. The flowering season of tree \#636 followed after that of tree \#446. Only $M$. festiva was trapped on this tree. From April to mid-
May 1999, both trees flowered again. Isonychus sp. 2 was the only scarab trapped. During the main flowering season in October-November 1999, Isonychus sp. 2 consisted of 16 collected specimens. This contrasts with the fact that it represented only two specimens in 1997. In all three flowering seasons, only 23 scarabs were trapped, and seven species were represented (C. ovulum, Isonychus sp. 2, M. festiva, M. nr. maculata, Macraspis sp. 2, sp. 3, and sp. 4).

Another mass-flowering tree species is A. pedicellaris that has reddish brush flowers of radial symmetry with small petals and many prominent stamens that are more conspicuous than the perianth. The flowering season of $A$. pedicellaris covered a period of about three weeks (8 October to 1 November 1997). Cyclocephala ovulum was collected regularly throughout the entire flowering season in 1997 but not in the 1999 flowering season. With four species $(C$. ovulum, Isonychus sp. 1 and sp. 2, and P. osculatii) and the second most number of individuals $(n=24)$, Scarabaeidae were among the most abundantly trapped beetles on $A$. pedicellaris (Table 2).

Small white flowers of the generalist syndrome and mass-flowering also characterize $T$. guianensis. The flowering season of T. guianensis lasted 9-27 November in 1997. One of the most abundant scarab species recorded on T. guianensis was M. festiva followed by Macraspis pseudochrysis Landin. The trapping period during the non-flowering interval lasted about 4.5 months, but only single specimens of P. osculatii and Stenocrates rufipennis (Fabricius) were collected. Altogether, four scarab beetle species and 12 individuals were collected from $T$. guianensis (Table 2).

Three scarab species (Pelidnota aciculata (F. Bates), Plectris sp., and one unidentified melolonthine species) represented by nine individuals were collected on $R$. trichanthera in the course of the year (Table 2). No specimens were sampled with the window traps during a four-month trapping 
Table 4. Occurrence of Barybas sp. 3 in the canopy of tree species in a lowland Venezuelan rainforest, 1997-1999.

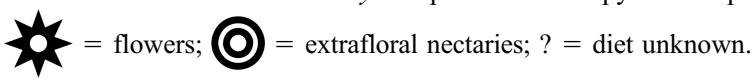

Host tree

Number of individuals and diet

Hymenopus heteromorphus

Dialium guianense

${ }_{1}$

Ocotea aff. amazonica

Licania hebantha

10

Dioclea scabra

Phthirusa stelis

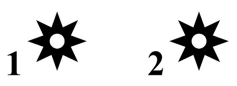

Goupia glabra

2 ?

Jun $98 \quad$ Jul $98 \quad$ Aug $98 \quad$ Sep $97 \quad$ Oct $97 \quad$ Mar 99

period. Among the abundant species was the nocturnal Plectris sp., which was observed feeding mainly on extrafloral nectaries only on $R$. trichanthera (Table 2).

Licania hebantha and M. subarachnophylla produce extrafloral nectar on flushing pubescent leaves. During the flush, seven scarab beetles belonging to three species (Barybas sp. 3, P. osculatii, and P. polita complex) were collected on $L$. hebantha and seven individuals in four species (C. ovulum, P. osculatii, $P$. valgus, and $S$. cf. carbo) on $M$. subarachnophylla. While $P$. polita complex fed only on $L$. hebantha and $S$. cf. carbo only on M. subarachnophylla, P. osculatii visited both tree species (Table 2).

\section{Discussion}

Species Characteristics. Cyclocephala ovulum occurred regularly on flowers of $A$. pedicellaris, indicating that there is also a host association with Fabaceae. Cyclocephala ovulum in the study plot fed on diverse flowers and was also observed feeding on extrafloral nectar. Cyclocephalini are most closely associated with early diverging angiosperm groups, where they feed, mate, and receive the benefit of thermal rewards from the host plant (Moore and Jameson 2013). Adult cyclocephaline beetles have been shown to contribute to pollination in the Annonaceae, Araceae, Arecaceae, Cyclanthaceae, Magnoliaceae, and Nymphaeaceae, and at least 97 cyclocephaline species have been reported from the flowers of 58 plant genera representing 17 families (Young 1986; Gottsberger 1989; Moore and Jameson 2013). Cyclocephala is a large genus that currently contains about 360 species (Ratcliffe and Cave 2017), although new species are being described continuously. Several species of Cyclocephala are known to feed upon (and pollinate) the flowers of aroids and certain palms, and some are the principal or exclusive pollinators of some plant genera within Araceae and Annonaceae. The beetles are attracted by odor and

Table 5. Occurrence of Isonychus sp. 2 in the canopy of tree species in a lowland tropical rainforest in Venezuela, 1997-1999. All individuals were feeding on flowers.

\begin{tabular}{|c|c|c|c|c|c|c|}
\hline Host tree species & & & Numbe & dividuals & & \\
\hline Hymenopus heteromorphus & & & 5 & & & \\
\hline Albizia pedicellaris & & 1 & & & & \\
\hline Matayba guianensis & 1 & 1 & & 1 & 15 & 1 \\
\hline & Sep 97 & Oct 97 & Mar 99 & May 99 & Oct 99 & Nov 99 \\
\hline
\end{tabular}


Table 6. Occurrence of Macraspis festiva in the canopy of tree species in a lowland tropical rainforest in Venezuela, 1997-1999.

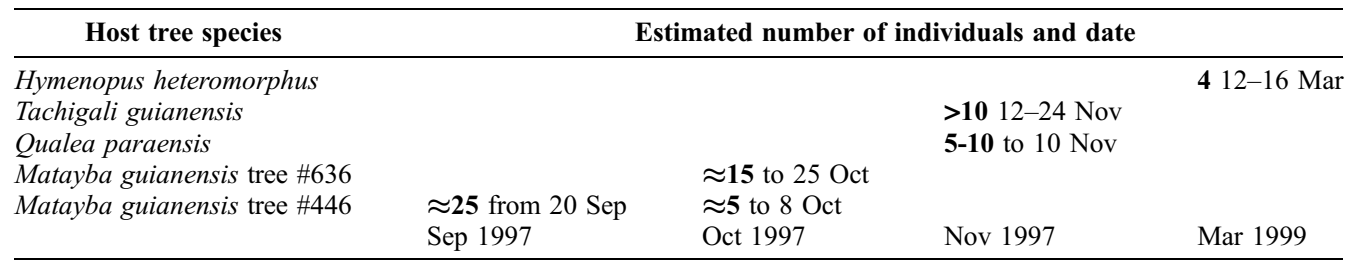

temperature and use the flowers as food or for areas for mating (Young 1986; Gottsberger 1989; Moore and Jameson 2013). Only members of Cyclocephala have been recorded from dicot flowers, and only in the New World (Moore and Jameson 2013). Dicot families recorded as host plants include Asteraceae (Hayward 1946), Lecythidaceae (Prance 1976), and Cactaceae (Lenzi and Orth 2011).

Another eight species of Cyclocephala were recorded from the study plot, but host associations or occurrence in the canopy were not clear because Cyclocephala species are often specialized for specific plant species and families (e.g., Araceae), which were not included in this study. An example is Cyclocephala colasi Endrödi that was collected with 25 often pollen-loaded individuals, but only two specimens were sampled on canopy trees. This species is known to be associated with the Amazonian arum lily Philodendron solimoesense A.C. $\mathrm{Sm}$. (Araceae), which grows in the understory (Seymour et al. 2009).

Adults in the subfamily Rutelinae are known to feed on leaves or not to take any nourishment (Scholtz and Chown 1995). The exclusively Neotropical tribe Geniatini Burmeister includes 13 genera and 323 described species, and they inhabit semideciduous and cloud forests (Pereira et al. 2013). The single species of Leucothyreus that was collected in the canopy of the crane plot fed on mature leaves. It was the only leaf-feeding species of the observed scarab community in the canopy.

Four nocturnal species of Pelidnota were recorded in the study plot feeding on flowers and extrafloral nectaries, whereas the species of diurnal

Table 7. Occurrence of Pelidnota osculatii in the canopy of tree species in a lowland tropical rainforest in Venezuela, 1997-1999. 2 = flowers; $(\mathbf{O}=$ extrafloral nectaries; ? = diet unknown.
Host tree species
Number of individuals and diet

\section{Emmotum acuminatum}

Hymenopus heteromorphus

Moquilea subarachnophylla

Albizia pedicellaris

Licania hebantha

Tachigali guianensis

1 ?

Goupia glabra

1 ?

$\begin{array}{cccccccc}\text { May } & \text { Jun } & \text { Jul } & \text { Aug } & \text { Oct } & \text { Jan } & \text { Feb } & \text { Mar } \\ 98 & 98 & 98 & 97 & 97 & 99 & 99 & 99\end{array}$


Macraspis fed on flowers, consuming their petals and pollen. These are generalist beetles found on a wide variety of plants, including both monocotyledons and dicotyledons (Soula 2003). Larvae are saproxylophagous and develop in rotten wood (García et al. 2013). Macraspis species in the canopy study plot fed on diverse flowers, with the abundant $M$. festiva visiting flowering tree species over the entire flowering season and then moving to another flowering tree species. Macraspis festiva was recorded in the canopy from September to November as well in March. Garcia et al. (2013) reported pupae and larvae of this species from rotting logs in Brazil in January-April, August, and November, which indicates a multivoltine life cycle and year-round occurrence. Thus, M. festiva probably fed on non-sampled trees during other months in our study.

Species of Cnemida inhabit tropical moist and premontane forests of South and Central America (Jameson 1996). Adults have been collected on various flowering plants and from foliage. Recorded host plants are Bixa L. (Bixaceae), Mimosa L. and Inga Miller (both Fabaceae), Gossypium L. (Malvaceae), Psychotria L. (Rubiaceae), and Turneraceae. Adults are generally active from early morning to midday. This period of activity corresponds with the flowering timeframe of Turnera L., Bixa, Inga, and Mimosa (Jameson 1996). Cnemida retusa is recorded from Venezuela, Suriname, Guyana, Peru, French Guiana, Ecuador, Colombia, Bolivia, and northern Argentina (Jameson 1996). Adults have been observed feeding on the buds and flowers of roses (Rosaceae) (Araújo e Silva et al. 1968). Cnemida leprieuri is known from Suriname, French Guiana, the Amazon Basin, Peru, and Bolivia (Jameson 1996). In our canopy study plot, both species preferred feeding on the flowers of the liana D. scabra.

Many adult melolonthines do not feed, whereas others feed on flowers or leaves (Scholtz and Chown 1995). The single species of Plectris in the canopy study plot fed exclusively on the extrafloral nectaries of $R$. trichanthera from January to March. Plectris adults in Colombia become most active in October and November (Pardo-Locarno et al. 2005). The two species of Isonychus in the study plot fed on diverse flowers. Two species of Barybas in the study plot fed mainly on flowers. Andrade et al. (1996) found Barybas species feeding on flowers of Xylopia brasiliensis Sprengel (Annonaceae).

Diet. Beetles in flowers presumably take nectar, feed on flower parts, or feed on pollen as adults (Samuelson 1994). Beetles find flowers by certain cues, especially color (Waser 1983) and scent (Gottsberger 1989). On 145 plant species in a tropical monsoon forest in Laos, Coleoptera were the second most abundant visitor group ( $16 \%$ of all individuals), and Scarabaeidae were among the most abundant families (Kato et al. 2008). Scarabaeidae visiting flowers in canopy trees were reported as well from Bornean (Kato et al. 2000) and Australian rainforests (Kitching et al. 2007). Our data in the Venezuelan canopy crane plot where species-rich scarab assemblages were found on flowering trees compare favorably with these findings in Asia and Australia. Cyclocephala ovulum and M. festiva, which showed temporal flower constancy, might contribute to pollination even in more generalist flowers.

Scarabaeidae exhibit an evolutionary transition from a coprophagous to a phytophagous lifestyle (Grimaldi and Engel 2005), and several different associations with flowers exist (Schiestl and Dötterl 2012). However, the flower-visiting scarabs in the canopy crane plot showed comparable resource use behavior. Six of eight species of Melolonthinae were associated with flowers. This contrasts with the traditional view that the adults of some basal groups of phytophagous scarabs, including Melolonthinae, do not visit flowers but rather feed on leaves (Leal 1998; Krell 2006). Conversely, flower visitation is known within a derived, monophyletic group of scarabs consisting of Rutelinae, Dynastinae, and Cetoniinae (Browne and Scholtz 1999; Smith 2006). Anthophilous groups are relatively young with an estimated origin in the Paleocene around 60 mya (Krell 2006). The fact that florivory obviously prevails in canopy scarabs might be attributed to the unpalatability of leaves (Cates and Rhoades 1977; Novotny et al. 2003), while flowers generally contain lower concentrations of defensive chemicals (Irwin et al. 2004). Furthermore, except for Leucothyreus sp., no scarab species were found feeding on leaves. The majority of the most abundant beetles could be associated with a distinct nonfoliar diet.

The visitation of beetles to extrafloral nectaries has been recorded on Cucurbitaceae (Agarwal and Rastogi 2010) as well as at foliar nectaries of Byttneria aculeata (Jacq.) (Sterculiaceae) in lowland Costa Rica (Hespenheide 1985). However, there are no published reports of scarab species feeding on extrafloral nectaries. This is surprising because eight scarab species were observed consuming this diet in the canopy crane plot, and they represented almost a fourth of the entire canopy assemblage. Furthermore, the extrafloral nectarsecreting young leaves of $L$. hebantha and $M$. subarachnophylla attracted three and four scarab species, respectively. Extrafloral nectar does not differ significantly from floral nectar and also does not show differences between accessible nectar of open flowers and nectar protected by narrow corolla tubes (Blüthgen et al. 2004). Thus, beetles feeding on floral nectar should be expected to feed also on 
extrafloral nectar. Note that Plectris sp. $(n=5)$ was found exclusively consuming extrafloral nectar.

In the tropics, many plants often flower without regularity and synchrony, which is in contrast to temperate forests (Sakai 2001). Newstrom et al. (1994) demonstrated that, in spite of an annual rhythm observed at the community level, only $29 \%$ of trees showed an annual flowering pattern in Costa Rica where the predominant flowering pattern was subannual (flowering more than once a year, often irregularly), accounting for $55 \%$ of the trees. Studies carried out in the crane study plot at Surumoni validate data collected from other areas. The flowering phenology of 54 species of canopy trees showed temporally non-annual reproductive patterns in about $35 \%$ of the species. Moreover, $27 \%$ of all trees showed a single flowering event per year, while $25 \%$ showed several flowering periods per year; $12 \%$ of the trees flowered nearly continuously. The community flowering pattern showed a bimodal distribution with a first peak at the end of the dry season/beginning of the rainy season and a second peak in the transition period between the rainy and dry seasons (Wesenberg 2004).

As flowering in tropical canopy trees is often unpredictable and temporally limited, it is expected that flower-visiting scarabs should be able to utilize flowers of various tree species. Thus, 11 out of 21 exclusively flower-visiting scarabs were recorded on at least two different canopy tree species. This foraging behavior was particularly demonstrated by $M$. festiva switching from the mass-flowering $M$. guianensis \#446 to \#636, then moving to the massflowering $Q$. paraensis, and thereafter to the massflowering $T$. guianensis. The same phenomenon might apply to other flower-visiting scarabs in the canopy crane plot and is suggested by studies in the understory. The mean distance that Cyclocephala species moved within one night was $83 \mathrm{~m}$ with a range of 1-529 $\mathrm{m}$, and one flight of $1,350 \mathrm{~m}$ was recorded between visits to Dieffenbachia longispatha Engl. and K. Krause (Araceae) (Young 1988).

Cyclocephaline species are generally oligophagous or polyphagous. For cyclocephaline species with multiple host records, only seven species were recorded from a single host-plant genus (monophagous), 23 species have been reported from multiple host-plant genera within a family (oligophagous), and 27 species have been recorded from multiple host-plant families (polyphagous) (Moore and Jameson 2013). Among the species of Cyclocephala in the canopy crane plot, only C. ovulum was clearly identified as polyphagous, feeding on four unrelated canopy tree species.

Host specificity for insects is defined as the taxonomic range of plant species utilized and the plant parts preferred (Janzen 1973). Scarab species $(n=17)$ in the canopy crane plot, particularly the more abundant scarabs, often fed on different plants. Numerous host records may be caused by polyphagy, which enables higher beetle abundance compared to oligophagous species. Otherwise, as abundant species are more frequently sampled, they are more likely to be found on a higher variety of host plants. Thus, rare species always seem more specialized than they truly are (Ødegaard 2000). Host specificity is an evolutionarily labile property (Wasserman and Futuyma 1981; Radtkey and Singer 1995), and often a species, as a whole, has a greater host range than a single individual of the same species (Fox and Morrow 1981; Mawdsley and Stork 1997). Furthermore, host affiliations can vary geographically (Fox and Morrow 1981) both in specialist (Thompson 1999) and in generalist insects (Sword and Dopman 1999). Examples may be $C$. retusa as well as $M$. pseudochrysis, which fed on flowers of T. guianensis in the study plot but also feed in inflorescences of the palm Euterpe oleracea Mart. in October, November, and February in the eastern Amazon region of Brazil (Jesus-Barro et al. 2013).

Community Assemblage. Compared to other beetle families dominating the canopies of tropical forests, Scarabaeidae are usually less prominent inhabitants, although they were the sixth speciesrich beetle family in the canopy crane plot. Only 33 of 854 beetle species in 44 families recorded on 25 canopy plant species of the study plot were Scarabaeidae. Also, studies in other tropical forest canopies commonly report few scarab species. Stork and Grimbacher (2006) recorded 36 scarab species from a lowland tropical rainforest in Australia, and Hammond et al. (1997) reported 16 scarab species in Sulawesi. However, on some mass-flowering tree species, e.g., H. heteromorphus, Scarabaeidae might appear with many species and in high numbers. As in the canopy crane plot, the subfamilies Dynastinae, Melolonthinae, and Rutelinae predominated in samples from a premontane rainforest in Costa Rica (García-López et al. 2010); comparable to the canopy crane plot community, Melolonthinae had the lowest number of species and individuals.

The scarab community in our canopy study area tended to accumulate on single trees, particularly flowering trees such as $H$. heteromorphus on which 12 species were observed. Scarab beetle species share many hosts and the same diet. In our study, Cnemida and Isonychus had some species occur together on host trees. Four species of Macraspis co-occurred on the flowers of $M$. guianensis and $H$. heteromorphus. Aggregations of congeneric species are known for Cyclocephala species where a single inflorescence can contain multiple species. An extreme example is Dieffenbachia nitidipetiolata Croat and Grayum that was visited by at least 
nine Cyclocephala species in Costa Rica (Young 1990). These multi-species aggregations might be explained if floral scents are also serving as surrogate sex pheromones for multiple cyclocephaline species (Schatz 1990). This hypothesis may be supported by the observations of Gottsberger et al. (2012) who observed that Cyclocephala literata Burmeister will aggregate due to floral scent compounds alone. Such congeneric aggregations suggest that niche requirements among these species are similar.

The sympatric co-occurrence of congeneric species is remarkable because species with identical ecological requirements cannot coexist temporally and spatially (Mayr 1979). Typically, there are small differences either in habitat use or behavior for such species. For instance, niche width and overlap in sympatric bark beetles were affected by resource availability, arrival sequence, and attack density (Amezaga and Rodríguez 1998). Two sympatric species of Phaleria Latreille (Tenebrionidae) showed differences in their zonation and habitat preferences (Deidun et al. 2010). Two sister species of leaf beetles in the genus Chrysochus Chevrolat (Chrysomelidae) showing overlapping host associations used a different number of milkweed host plants, with one species monophagous and the other feeding on three different plant species (Dobler and Farrell 1999). The co-occurring species of Macraspis in our canopy study area seemed to differ in their host preferences as well as overall abundances. While M. festiva was sampled 15 times on $M$. guianensis (32 individuals collected), $M$. $\mathrm{nr}$. maculata was collected on this tree species only twice (11 individuals collected). The reason(s) for this difference is unknown.

Activity. Scarabs in our canopy study area were active on their host trees either at night or during the day. Macraspis species were found on their host trees during the day, and species of Pelidnota, Dynastinae, and Melolonthinae were only evident at night. Such distinct diel activity patterns are well known in most scarab groups, and they may reflect simple evolutionary constraints (Kronfeld-Schor and Dayan 2003). A study in Borneo showed dung beetle activity in the canopy, with most species being active only during the day and with clear specification of activity peaking at midday or at dawn/dusk (Davis et al. 1997). Dung and carrion beetles in a tropical forest in French Guiana could be categorized as typically diurnal, nocturnal, or crepuscular species (Feer and Pincebourde 2005). Strong diel activity patterns may coincide with anthesis. For instance, flowers of Turnera, Bixa, Inga, and Mimosa generally bloom in early morning, and by midday the petals close and wilt (Elias et al. 1975; Janzen 1983; Koptur 1994).

Resting was observed for few species. The diurnal $C$. retusa was quiescent on the forest floor at night, demonstrating that some beetles shift between forest strata during periods of activity and non-activity. Others, like M. festiva, are hidden at night between leaves away from their host trees. Unpredictable occurrence or retreat to hiding places during rest may lower predatory pressure. Moreover, presence on host trees only during times of activity may reduce inter- and intraspecific competition. On the other hand, the shift between strata might be related to specific microclimate conditions in the rainforest canopy. Tree canopies are exposed habitats, and during the day they can be hot and dry and receive high solar insolation. Levels of solar radiation, fluctuations in relative humidity and air temperature, and wind velocities are noticeably higher in the upper canopy than in the understory (Parker 1995; Szarzynski and Anhuf 2001). Thus, most species will deal either with daytime or nighttime conditions and avoid extreme conditions during quiescence.

Some abundant scarab species in the canopy crane plot were present in most months of the year (e.g., Barybas sp. 3, C. ovulum, C. retusa, Isonychus sp. 2, M. nr. maculata, P. osculatii). This indicates year-round occurrence and possibly multivoltine life cycles. Species restricted in their occurrence to a few months may either exhibit seasonality or they just did not visit the canopy host plants studied at those periods. The patchy distribution and movement of scarab beetles among different hosts may result in a false perception of seasonality if sampled only at one locality in the forest.

However, most tropical insects show accentuated seasonality (Wolda 1989, 1992) that is probably related to tree phenological events, such as leaf shedding and budding, flowering, and fruiting (Janzen 1975; Larcher 2000). Investigations on Curculionidae in Panama showed activity patterns of species that occurred only during short periods or up to an entire year, and many species showed

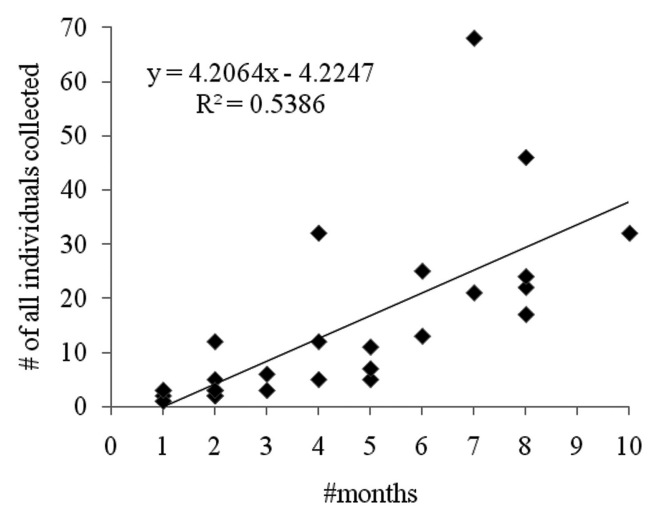

Fig. 6. Total number of individuals sampled per scarab beetle species regressed on the number of months of occurrence, Venezuela, 1997-1999. 
similar seasonal patterns in successive years (Wolda 1988). This is supported by a light-trapping study in the premontane rainforest in Costa Rica (GarcíaLópez et al. 2010). Some of the dynastine species found were highly seasonal (e.g., Cyclocephala williami Ratcliffe), whereas others had a distinct aseasonality covering most of the sampling time (e.g., Pelidnota parallela (Hardy)). Among 13 species of Melolonthinae and Rutelinae, eight showed clear seasonality in occurrence and abundance in a Bornean rainforest (Kishimoto-Yamada and Itioka 2012).

Martínez et al. (2009) observed that there was a significant shift in community structure between the dry season and the rainy season for 14 scarab species in successional forest fragments of western Puerto Rico. The reason is most likely related to a taxon-specific interaction of stage of life cycle and seasonality. Specifically, the species of Phyllophaga Harris (Melolonthinae) were univoltine, whereas all other species were multivoltine. Nevertheless, appropriate food resources may result in higher activity and higher capture rates (e.g., M. festiva at $M$. guianensis and T. guianensis in our study), and thus do not necessarily depend on life cycles or seasonality. The flight activity of Phyllophaga lissopyge (Bates) in Colombia generally occurs more abundantly during the two rainy seasons, either March to May or September to November, but it was captured during every month of the year with the exception of August (Morales-Rodriguez et al. 2011). Still, more abundant and polyphagous species such as Barybas sp. 3, C. retusa, or P. osculatii are likely to be collected in more months of the year compared to rare species. The relationship between abundance and seasonality is illustrated by regressing the total number of individuals sampled per scarab species on the number of months collected (Fig. 6).

\section{Conclusions}

This study is the first long-term observation of a scarab beetle community inhabiting the canopy of a Neotropical rainforest. Moreover, this study combined multiple sampling techniques as well as continued sampling and observations of scarabs during the day and night. Specimens included in this study were identified, in part, to species level $(n=$ 18). The Surumoni crane project was one of the first crane facilities established worldwide and has, thus far, remained the only one within the world's largest rainforest area, the Amazon Basin (Winkler and Listabarth 2003).

One complete year of sampling revealed a total of 33 scarab species. Host records, adult food resource, diurnal/nocturnal activity, and switching behavior between canopy trees were documented for many species. The majority of the scarab community subsists on flowers, with up to 12 species aggregating on a single flowering tree. Some of the abundant species exhibited temporal flower constancy on mass-flowering canopy trees. New to science is that Scarabaeidae may temporally visit canopy trees that secrete extrafloral nectar during leaf flush. The results suggest that canopy scarab beetles are temporally associated with distinct canopy hosts. Their distribution coincides with the availability of appropriate food resources. Thus, the composition of canopy inhabiting scarab communities is temporally changing among tree species.

\section{ACKNowledgments}

Susan Kirmse cordially thanks the Austrian Academy of Sciences and colleagues for their support and permission to join the Surumoni project. The fieldwork was supported, in part, by a travel grant from the ESF Tropical Canopy Programme and a grant from the Stiftung der Deutschen Wirtschaft. We thank two anonymous reviewers for providing valuable commentary on the manuscript.

\section{References Cited}

Adis, J., A. J. Harada, C. R. V. da Fonseca, W. Paarmann, and J. A. Rafael. 1998. Arthropods obtained from the Amazonian tree species "cupiuba" (Goupia glabra) by repeated canopy fogging with natural pyrethrum. Acta Amazonica 28: 273-283.

Adis, J., Y. D. Lubin, and G. Montgomery. 1984. Arthropods from the canopy of inundated and terra firme forests near Manaus, Brazil, with critical considerations on the pyrethrum-fogging technique. Studies on Neotropical Fauna and Environment 4: 223-236.

Agarwal, V. M., and N. Rastogi. 2010. Ants as dominant insect visitors of the extrafloral nectaries of sponge gourd plant, Luffa cylindrica (L.) (Cucurbitaceae). Myrmecology 3: 45-54.

Allison, A., G. A. Samuelson, and S. E. Miller. 1993. Patterns of beetle species diversity in New Guinea rain forest as revealed by canopy fogging: Preliminary findings. Selbyana 14: 16-20.

Amezaga, I., and M. Á. Rodríguez. 1998. Resource partitioning of four sympatric bark beetles depending on swarming dates and tree species. Forest Ecology and Management 109: 127-135.

Andrade, B. M., A. T. Oliveira-Filho, and A. R. Soares. 1996. Pollination and breeding system in Xylopia brasiliensis Sprengel (Annonaceae) in southeastern Brazil. Journal of Tropical Ecology 12: 313-320.

Anhuf, D., T. Motzer, R. Rollenbeck, B. Schröder, and J. Scarzynski. 1999. Water budget of the Surumoni crane site (Venezuela). Selbyana 20: 179-185. 
Araújo e Silva, G. A., C. R. Gonçalves, D. M. Galvão, A. J. L. Gonçalves, J. Gomes, M. do Nascimento Silva, and L. de Simoni. 1968. Quarto Catalogo dos Insetos que Vivem nas Plantas do Brasil, seus Parasitos e Predadores. Parte 2, Volume 1 (Insetos, Hospedeiros e Inimigos Naturais). Ministerio da Agricultura, Laboratorio Central de Patalogia Vegetal, Rio de Janeiro, Brazil.

Arndt, E., S. Kirmse, and T. L. Erwin. 2001. Arboreal beetles of Neotropical forests: Agra Fabricius, larval description with notes on natural history and behaviour (Coleoptera, Carabidae, Lebiini, Agrina). The Coleopterists Bulletin 55: 297-311.

Basset, Y., and A. H. Arthington. 1992. The arthropod community of an Australian rainforest tree: Abundance of component taxa, species richness and guild structure. Australian Journal of Ecology 17: 89-98.

Basset, Y., L. Cizek, P. Cúenoud, R. K. Didham, F. Guilhaumon, O. Missa, V. Novotny, F. Ødegaard, T. Roslin, J. Schmidl, A. K. Tishechkin, N. N. Winchester, D. W. Roubik, H.-P. Aberlenc, J. Bail, H. Barrios, J. R. Bridle, G. CastañoMeneses, B. Corbara, G. Curletti, W. Duarte de Rocha, D. M. Bakker, J. H. C. Delabie, A. Dejean, L. L. Fagan, A. Floren, R. L. Kitching, E. Medianero, S. E. Miller, E. Gama de Oliviera, J. Orivel, M. Pollet, M. Rapp, S. P. Ribeiro, Y. Roisin, J. B. Schmidt, L. Sørensen, and $M$. Leponce. 2012. Arthropod diversity in a tropical forest. Science 338: 1481-1484.

Basset, Y., N. D. Springate, H.-P. Aberlenc, and G. Delvare. 1997. A review of methods for sampling arthropods in tree canopies [pp. 27-52]. In: Canopy Arthropods (N. E. Stork, J. A. Adis, and R. K. Didham, editors). Chapman and Hall, London, UK.

Blüthgen, N., G. Gottsberger, and K. Fiedler. 2004. Sugar and amino acid composition of ant-attended nectar and honeydew sources from an Australian rainforest. Australian Ecology 29: 418-429.

Bouchard, P., Y. Bousquet, A. E. Davies, M. A. AlonsoZarazaga, J. F. Lawrence, C. H. C. Lyal, A. F. Newton, C. A. M. Reid, M. Schmitt, S. A. Ślipiński, and A. B. T. Smith. 2011. Family-group names in Coleoptera (Insecta). ZooKeys 88: 1-972.

Browne, J., and C. H. Scholtz. 1999. A phylogeny of the families of Scarabaeoidea (Coleoptera). Systematic Entomology 24: 51-84.

Cates, R. G., and D. F. Rhoades. 1977. Patterns in the production of antiherbivore chemical defenses in plant communities. Biochemical Systematics and Ecology 5: 185-193.

Coley, P. D., and J. A. Barone. 1996. Herbivory and plant defenses in tropical forests. Annual Review of Ecology and Systematics 27: 305-335.

Davis, A. J., J. Huijbregts, A. H. Kirk-Spriggs, J. Krikken, and S. L. Sutton. 1997. The ecology and behaviour of arboreal dung beetles in Borneo [pp. 417-432]. In: Canopy Arthropods (N. E. Stork, J. Adis, and R. Didham, editors). Chapman and Hall, London, UK.

Deidun, A., A. Pawley, and P. J. Schembri. 2010. Distribution and biology of two sympatric Phaleria species (Coleoptera: Tenebrionidae) on Maltese beaches. Rapport du Congrès de la Commission Internationale pour l'Exploration Scientifique de la Mer Méditerranée 39: 737.

Dinerstein, E., D. M. Olson, D.J. Graham, A. L. Webster, S. A. Primm, M. P. Bookbinder, G. Ledec, and World Wildlife Fund. 1995. A conservation assessment of the terrestrial ecoregions of Latin America and the Caribbean. World Bank Washington, DC. documents.worldbank.org/ curated/en/957541468270313045/A-conservationassessment-of-the-terrestrial-ecoregions-of-LatinAmerica-and-the-Caribbean (accessed 12 December 2017).

Dobler, S., and B. D. Farrell. 1999. Host use evolution in Chrysochus milkweed beetles: Evidence from behaviour, population genetics and phylogeny. Molecular Ecology 8: 1297-1307.

Dyer, L. A. 1995. Tasty generalists and nasty specialists? Antipredator mechanisms in tropical lepidopteran larvae. Ecology 76: 1483-1496.

Elias, T. S., W. R. Rozich, and L. Newcombe. 1975. The foliar and floral nectaries of Turnera ulmifolia L. American Journal of Botany 62: 570-576.

Engwald, S., V. Schmit-Neuerburg, and W. Barthlott. 2000. Epiphytes in rain forests of Venezuela diversity and dynamics of a biocenosis [pp. 425-434]. In: Results of Worldwide Ecological Studies. Proceedings of the 1st Symposium by the A. F. W Schimper-Foundation - from H. and E. Walter - Hoheneim, Oktober 1998 (S. W. Breckle, B. Schweizer, and U. Arndt, editors). Verlag Günter Heimbach, Stuttgart-Hohenheim, Germany.

Erwin, T. L. 1982. Tropical forests: Their richness in Coleoptera and other arthropod species. The Coleopterists Bulletin 39: 74-75.

Erwin, T. L. 1990. Canopy arthropod biodiversity: A chronology of sampling techniques and results. Revista Peruana de Entomologia 32: 71-77.

Erwin, T. L. 1994. Arboreal beetles of tropical forests: The Xystosomi group, subtribe Xystosomina (Coleoptera: Carabidae: Bembidiini), Part I. Character analysis, taxonomy and distribution. Canadian Entomologist 26: 549-666.

Feer, F., and S. Pincebourde. 2005. Diel flight activity and ecological segregation within an assemblage of tropical forest dung and carrion beetles. Journal of Tropical Ecology 21: 21-30.

Floren, A., and K. E. Linsenmair. 1998. Diversity and recolonization of arboreal Formicidae and Coleoptera in a lowland rain forest in Sabah, Malaysia. Selbyana 19(2): 155-161.

Fox, L. R., and P. A. Morrow. 1981. Specialization: Species property or local phenomenon? Science 211: 887-893.

Futuyma, D. J., and S. S. Wasserman. 1980. Resource concentration and herbivory in oak forests. Science 210: 920-922.

Garcia, F. P., S. R. Rodrigues, C. A. C. Bagnara, and D. S. Oliveira. 2013. Survey of saproxylophagous Melolonthidae (Coleoptera) and some biological aspects in Aquidauana, MS. Biota Neotropica 13: 38-43.

García-López, A., E. Micó, C. Numa, and E. Galante. 2010. Spatiotemporal variation of scarab beetle 
assemblages (Coleoptera: Scarabaeidae: Dynastinae, Melolonthinae, Rutelinae) in the premontane rain forest in Costa Rica: A question of scale source. Annals of the Entomological Society of America 103: 956-964.

Gottsberger, G. 1989. Beetle pollination and flowering rhythm of Annona spp. (Annonaceae) in Brazil. Plant Systematics and Evolution 167: 165-187.

Gottsberger, G., I. Silberbauer-Gottsberger, R. S. Seymour, and S. Dötterl. 2012. Pollination ecology of Magnolia ovata may explain the overall large flower size of the genus. Flora- Morphology, Distribution, Functional Ecology of Plants 207: 107-118.

Grimaldi, D., and M. S. Engel. 2005. Evolution of the Insects. Cambridge University Press, New York, NY.

Grimbacher, P. S., and N. E. Stork. 2009. Seasonality of a diverse beetle assemblage inhabiting lowland tropical rain forest in Australia. Biotropica 41: 328-337.

Hammond, P. M., N. E. Stork, and M. J. D. Brendell. 1997. Treecrown beetles in context: A comparison of canopy and other ecotone assemblages in a lowland tropical forest in Sulawesi [pp. 184-223]. In: Canopy Arthropods (N. E. Stork, J. Adis, and R. K. Didham, editors). Chapman and Hall, London, UK.

Hayward, K. J. 1946. Departamento de Entomología. Revista Industrial y Agrícola de Tucumán 36: 60-72.

Hespenheide, H. A. 1985. Insect visitors to extrafloral nectaries of Byttneria aculeata (Sterculiaceae): Relative importance and roles. Ecological Entomology 10: 191-204.

Irwin, R. E., L. S. Adler, and A. K. Brody. 2004. The dual role of floral traits: Pollinator attraction and plant defense. Ecology 85: 1503-1511.

Jameson, M. L. 1996. Revision and phylogeny of the Neotropical genus Cnemida (Coleoptera: Scarabaeidae: Rutelinae). Insecta Mundi 10(1-4): 285-315.

Janzen, D. H. 1973. Sweep samples of tropical foliage insects: Effects of seasons, vegetation types, elevation, time of day and insularity. Ecology 54: 687-708.

Janzen, D. H. 1975. Ecology of Plants in the Tropics. Edward Arnold, London, UK.

Janzen, D. (editor). 1983. Costa Rican Natural History. University of Chicago Press, Chicago, IL.

Jesus-Barros, C. R., L. Silva Freitas, and P. Coelho Grossi. 2013. Report of Macraspis pseudochrysis Landin, 1956 (Coleoptera: Scarabaeidae: Rutelinae) on açai palms (Euterpe oleracea Mart.) in floodplains in the state of Amapá, Brazil. Biota Neotropica 13: 380-382.

Kato, M., T. Itioka, S. Sakai, K. Momose, S. Yamane, A. A. Hamid, and T. Inoue. 2000. Various population fluctuation patterns of light-attracted beetles in a tropical lowland dipterocarp forest in Sarawak. Population Ecology 42: 97-104.

Kato, M., Y. Kosaka, A. Kawakita, Y. Okuyama, C. Kobayashi, T. Phimminith, and D. Thongphan. 2008. Plant-pollinator interactions in tropical monsoon forests in Southeast Asia. American Journal of Botany 95: 1375-1394.
Kishimoto-Yamada, K., and T. Itioka. 2012. Seasonality in phytophagous scarabaeid (Melolonthinae and Rutelinae) abundances in an 'aseasonal' Bornean rainforest. Insect Conservation and Diversity 6(2): 179-188. DOI: 10.1111/j.1752-4598.2012.00201.x.

Kitching, R. L., S. L. Boulter, B. G. Howlett, and K. Goodall. 2007. Visitor assemblages at flowers in a tropical rainforest canopy. Australian Journal of Ecology 32: 29-42.

Kitching, R. L., D. Li, and N. E. Stork. 2001. Assessing biodiversity 'sampling packages': How similar are arthropod assemblages in different tropical rainforests? Biodiversity and Conservation 10: 793-813.

Koptur, S. 1994. Floral and extrafloral nectaries of Costa Rican Inga trees: A comparison of their constituents and composition. Biotropica 26: 276-284.

Krell, F.-T. 2006. Fossil record and evolution of Scarabaeoidea (Coleoptera: Polyphaga). The Coleopterists Bulletin 60: 120-143.

Kronfeld-Schor, N., and T. Dayan. 2003. Partitioning time as an ecological resource. Annual Review of Ecology, Evolution, and Systematics 34: 153-181.

Larcher, W. (editor). 2000. Ecofisiologia Vegetal. Rima Artes e Textos, São Carlos, Brazil.

Leal, W. S. 1998. Chemical ecology of phytophagous scarab beetles. Annual Review of Entomology 43: 39-61.

Lenzi, M., and A. Orth. 2011. Visitantes florais de Opuntia monacantha (Cactaceae) em restingas de Florianópolis, SC, Brasil. Acta Biológica Paranaense 40: 19-32.

Martínez, N. J., N. M. Franz, and J. A. Acosta. 2009. Structure of the scarab beetle fauna (Coleoptera: Scarabaeoidea) in forest remnants of western Puerto Rico. Entomotropica 24: 1-9.

Mawdsley, N. A., and N. E. Stork. 1997. Host-specificity and effective specialization of tropical canopy beetles [pp. 104-130]. In: Canopy Arthropods (N. E. Stork, J. Adis, and R. K. Didham, editors). Chapman and Hall, London, UK.

Mayr, E. 1979. Animal Species and Evolution. The Belknap Press, Cambridge, MA.

Moore, M. R., and M. L. Jameson. 2013. Floral associations of cyclocephaline scarab beetles. Journal of Insect Science 13. DOI: 10.1673/031.013.10001.

Morales-Rodriguez, A., D. C. Peck, and P. S. Robbins. 2011. First record of the scarab beetle, Phyllophaga lissopyge from South America, with descriptions of adult seasonal activity and male response to sex attractants. Journal of Insect Science 11. DOI: 10.1673/ 031.011.0123.

Newstrom, L. E., G. W. Frankie, H. G. Baker, and R. K. Colwell. 1994. Diversity of long-term flowering patterns [pp. 142-160]. In: La Selva: Ecology and Natural History of a Neotropical Rain Forest (L. A. McDade, K. S. Bawa, H. A. Hespenheide, and G. S. Hartshorn, editors). University of Chicago Press, Chicago, IL.

Novotny, V., Y. Basset, and R. Kitching. 2003. Herbivore assemblages and their food resources [pp. 40-53]. In: Arthropods of Tropical Forests: Spatiotemporal Dynamics and Resource Use in the Canopy (Y. Basset, V. Novotny, S. Miller, and R. 
Kitching, editors). Cambridge University, Cambridge, UK.

Novotny, V., P. Drozd, S. E. Miller, M. Kulfan, M. Janda, Y. Basset, and G. D. Weiblen 2006. Why are there so many species of herbivorous insects in tropical rainforests? Science 313: 1115-1118.

Ødegaard, F. 2000. The relative importance of trees versus lianas as hosts for phytophagous beetles (Coleoptera) in tropical forests. Journal of Biogeography 27: 283-296.

Pardo-Locarno, L. C., J. Montoya-Lerma, A. C. Bellotti, and A. Van Schoonhoven. 2005. Structure and composition of the white grub complex (Coleoptera: Scarabaeidae) in agroecological systems of northern Cauca, Colombia. Florida Entomologist 88 : 355-363.

Parker, G. G. 1995. Structure and microclimate of forest canopies [pp. 73-98]. In: Forest Canopies (M. D. Lowman and N. M. Nadkarni, editors). Academic Press, San Diego, CA.

Prance, G. T. 1976. The pollination and androphore structure of some Amazonian Lecythidaceae. Biotropica 8: 235-241.

Prance, G. T. 1979. Notes on the vegetation of Amazonia III. The terminology of Amazonian forest types subject to inundation. Brittonia 31: 26-38.

Radtkey, R. R., and M. C. Singer. 1995. Repeated reversals of host-preference evolution in a specialist insect herbivore. Evolution 49: 351-359.

Ratcliffe, B. C. 1991. The scarab beetles of Nebraska. Bulletin of the University of Nebraska State Museum 12: 1-333.

Ratcliffe, B. C., and R. D. Cave. 2017. The dynastine scarab beetles of the United States and Canada (Coleoptera: Scarabaeidae: Dynastinae). Bulletin of the University of Nebraska State Museum 30: $1-304$.

Ratcliffe, B. C., and M. L. Jameson. 2005. Generic guide to New World scarabs. museum.unl.edu/research/ entomology/Guide/Guide-introduction/Guideintro. html (accessed 5 May 2018).

Ritcher, P. O. 1958. Biology of Scarabaeidae. Annual Review of Entomology 3: 311-334.

Sakai, S. 2001. Phenological diversity in tropical forests. Population Ecology 43: 77-86.

Samuelson, G. A. 1994. Pollen consumption and digestion by leaf beetles [pp. 179-183]. In: Novel Aspects of the Biology of Chrysomelidae (P. H. Jolivet, M. L. Cox, and E. Petitpierre, editors). Kluwer Academic Publishers, Dordrecht, The Netherlands.

Schatz, G. E. 1990. Some aspects of pollination biology in Central American forests [pp. 69-84]. In: Reproductive Ecology of Tropical Forest Plants (K. S. Bawa, and M. Hadley, editors). UNESCO and The Parthenon Publishing Group, Carnforth, UK and Park Ridge, NJ.

Schiestl, F. P., and S. Dötterl. 2012. The evolution of floral scent and olfactory preferences in pollinators: coevolution or pre-existing bias? Evolution 66(7): 2042-2055. DOI: 10.1111/j.1558-5646. 2012.01593.x.

Scholtz, C. H., and S. L. Chown. 1995. The evolution of habitat use and diet in Scarabaeoidea: A phylogenetic approach [pp. 355-374]. In: Biology,
Phylogeny, and Classification of Coleoptera (J. Pakaluk and S. A. Ślipiński, editors). Papers Celebrating the $80^{\text {th }}$ Birthday of Roy A. Crowson. 1. Muzeum i Instytut Zoologii PAN, Warsaw, Poland.

Schoonhoven, L. M., J. J.A. van Loon, and M. Dicke. 2005. Insect-Plant Biology, $2^{\text {nd }}$ edition. Oxford University Press, Oxford, UK.

Seymour, R. S., C. R. White, and M. Gibernau. 2009. Endothermy of dynastine scarab beetles (Cyclocephala colasi) associated with pollination biology of a thermogenic arum lily (Philodendron solimoesense). The Journal of Experimental Biology 212: 2960-2968.

Singer, M. S. 2008. Evolutionary ecology of polyphagy [pp. 29-42]. In: Specialization, Speciation, and Radiation: The Evolutionary Biology of Herbivorous Insects (K. J. Tilmon, editor). University of California Press, Los Angeles, CA.

Smith, A. B. T. 2006. An overview of the classification and evolution of the major scarab beetle clades (Coleoptera: Scarabaeoidea) based on preliminary molecular analyses. The Coleopterists Bulletin 60: $35-46$.

Soula, M. 2003. Rutelini 3 [pp. 29-79]. In: Les Coléoptères du Monde 29. Hillside Books, Canterbury, UK.

Stork, N. E. 1991. The composition of the arthropod fauna of Bornean lowland rainforest trees. Journal of Tropical Ecology 7: 161-180.

Stork, N. E., and P. S. Grimbacher. 2006. Beetle assemblages from an Australian tropical rainforest show that the canopy and the ground strata contribute equally to biodiversity. Proceedings of the Royal Society of London B 273: 1969-1975.

Sword, G. A., and E. B. Dopman. 1999. Developmental specialization and geographic structure of host plant use in a polyphagous grasshopper, Schistocerca emarginata (=lineata) (Orthoptera: Acrididae). Oecologia 120: 437-445.

Szarzynski, J., and D. Anhuf. 2001. Micrometerological conditions and canopy energy exchanges of a Neotropical rain forest (Surumoni-Crane Project, Venezuela). Plant Ecology 153: 231-239.

Thompson, J. N. 1999. What we know and do not know about coevolution: Insect herbivores and plants as a test case [pp. 7-30]. In: Herbivores: Between Plants and Predators (H. Olff, V. K. Brown, and R. H. Drent, editors). Blackwell Science, Oxford, UK.

Wardhaugh, C. W. 2014. The spatial and temporal distributions of arthropods in forest canopies: Uniting disparate patterns with hypotheses for specialization. Biological Reviews 89: 1021-1041.

Waser, N. M. 1983. The adaptive nature of floral traits: Ideas and evidence [pp. 241-285]. In: Pollination Biology (L. A. Real, editor). Academic Press, New York, NY.

Wasserman, S. S., and D. J. Futuyma. 1981. Evolution of host plant utilization in laboratory populations of the southern cowpea weevil, Callosobruchus maculatus Fabricius (Coleoptera: Bruchidae). Evolution 35: 605-617.

Wesenberg, J. 2004. Blühphänologie im Kronenraum eines tropischen Tieflandregenwaldes am Oberen Orinoco, Amazonas, Venezuela. Dissertation. 
Fakultät für Biowissenschaften, Pharmazie und Psychologie. Universität Leipzig, Germany.

Winkler, H., and C. Listabarth. 2003. Surumoni Project, Venezuela [pp. 126-136]. In: Studying Forest Canopies from Above: The International Canopy Crane Network (Y. Basset, V. Horlyck, and S. J. Wright, editors). Smithsonian Tropical Research Institute and UNEP, Balboa, Panama.

Wolda, H. 1988. Insect Seasonality: Why? Annual Review of Ecology and Systematics 19: 1-18.

Wolda, H. 1989. Seasonal cues in tropical organisms. Rainfall? Not necessarily! Oecologia 80: 437-442.

Wolda, H. 1992. Trends in abundance of tropical forest insects. Oecologia 89: 47-52.
Young, H. J. 1986. Beetle pollination of Dieffenbachia longispatha (Araceae). American Journal of Botany 73: 931-944.

Young, H. J. 1988. Neighborhood size in a beetle pollinated tropical aroid. Effects of low density and asynchronous flowering. Oecologia 76: 461-466.

Young, H. J. 1990. Pollination and reproductive biology of an understory Neotropical aroid [pp. 151-164]. In: Reproductive Ecology of Tropical Forest Plants (K. S. Bawa and M. Hadley, editors). UNESCO and The Parthenon Publishing Group, Carnforth, UK.

(Received 29 December 2017; accepted 13 December 2018. Publication date 25 March 2019.) 